\section{Música y Otorrinolaringología}

\section{Music and Otorhinolaryngology}

\author{
Paul Délano R. ${ }^{1}$
}

La música ha acompañado a la humanidad desde los orígenes de la civilización. Por ejemplo, se han encontrado flautas elaboradas con huesos de animales en sitios arqueológicos de neandertales y homo sapiens de hace 30 a 35 mil años, evidenciando que la música es una manifestación humana, que incluso parece haber precedido al desarrollo de la agricultura ${ }^{1}$.

Así como el lenguaje oral, la música puede transmitir mensajes, por lo que también se le considera como una función auditiva compleja. Por ejemplo, escuchar música puede evocarnos emociones positivas o negativas, dependiendo de sus componentes acústicos y de la memoria musical. Desde la neurociencia, se han comenzado a dilucidar los mecanismos neurobiológicos de la percepción musical. Uno de los circuitos cerebrales más conocidos es aquel que conecta el tálamo auditivo con la amígdala cerebral, involucrando redes neuronales de música y emoción. La percepción de la música incluye también diversas regiones de la corteza cerebral, como la corteza auditiva y áreas corticales involucradas en memoria auditiva, principalmente del hemisferio cerebral derecho. De esta forma, diversas patologías neurológicas y audiológicas pueden alterar la percepción musical ${ }^{2}$.

Los otorrinolaringólogos estamos fuertemente ligados a la música, tanto en nuestro desempeño profesional, como en nuestra vida privada. Se estima que cerca de un $12 \%{ }^{3}$ de los especialistas en otorrinolaringología son músicos, en un espectro que va desde aficionados, hasta músicos profesionales como Jorge Drexler en Uruguay. En el contexto clínico, muchas veces nos vemos enfrentados al músico como paciente. Esto debido a que los músicos están expuestos con regularidad a sonidos de altas intensidades (ensayos, tocatas y concier-
${ }^{1}$ Editor. Revista de Otorrinolaringología y Cirugía de Cabeza y Cuello. Departamento de Otorrinolaringología. Hospital Clínico de la Universidad de Chile. Santiago, Chile.

Correspondencia:

Dr. Carlos Lorca Tobar, 999

Servicio de Otorrinolaringología. Hospital Clínico Universidad de Chile. Independencia. Santiago, Chile.

Email: pdelano@med.uchile.cl tos), por lo que frecuentemente, presentan tinnitus o hipoacusias secundarias a trauma acústico. Es importante prevenir el daño auditivo en músicos, reforzando la educación para el uso de protectores auditivos. Por otro lado, la consulta por patologías que afectan a la voz es frecuente en cantantes, incluyendo aficionados, actores, cantantes de música popular y de alta exigencia vocal, como cantantes líricos. El conocimiento de las patologías vocales en cantantes, y su manejo, es muy importante para su correcto diagnóstico y tratamiento. De igual forma, la prevención de las patologías vocales en músicos es primordial, por lo que se debe aconsejar el entrenamiento formal para el uso de la voz profesional.

Por otro lado, la música, también puede ayudar a curar o paliar diversas patologías, en lo que se conoce como la musicoterapia. En el ámbito otorrinolaringológico, ésta ha sido utilizada en el manejo del tinnitus -con resultados aún preliminares-, o para aliviar el dolor en diversos procedimientos invasivos, como la reducción de fracturas nasales ${ }^{4}$. Recientemente, el tema de "Música y Otorrinolaringología" fue presentado y discutido como curso precongreso en el LXXVII Congreso Chileno de Otorrinolaringología, realizado en formato híbrido en La Serena, Pirque y Punta Arenas. El mensaje final de este curso (take home message), fue que el otorrinolaringólogo debiera ser el médico acompañante y consejero de los músicos, para cuidar de su salud auditiva y laríngea. De esta forma, como otorrinolaringólogos debemos tener un adecuado conocimiento de la profesión del músico, y manejar, al menos a nivel básico, el léxico musical. Como editor, los invito a enviar trabajos de investigación o revisiones que estudien los diversos ámbitos de interacción entre Música y Otorrinolaringología. 


\section{EDITORIAL}

\section{Bibliografía}

1. Conard NJ, Malina M, Münzel SC. New flutes document the earliest musical tradition in southwestern Germany. Nature. 2009;460(7256):737740. doi: 10.1038/nature08169.

2. Wipe B, Kuroiwa M, Delano PH. Trastornos de la percepción musical. Rev Otorrinolaringol Cir Cabeza Cuello. 2013;73(2):189-199. doi: 10.4067/S071848162013000200012.
3. Goycoolea M. Cerebros musicales. Curso Precongreso. LXXVII Congreso Chileno de Otorrinolaringología. Formato hibrido, La Serena, Pirque, Punta Arenas, 2021.

4. Ortega A, Gauna F, Munoz D, Oberreuter G, Breinbauer HA, Carrasco L. Music Therapy for Pain and Anxiety Management in Nasal Bone Fracture Reduction: Randomized Controlled Clinical Trial. Otolaryngol Head Neck Surg. 2019;161(4):613-619. doi: $10.1177 / 0194599819856604$. 